\title{
Determining Energy of Elastic waves Caused by Earthquake (*)
}

\author{
V. I. Belotelov, N. V. Kondorskaya, E. TH. SAVARENSKY \\ Ricevuto il 7 dicembre 1960
}

The recent achievements in seismology and the development of the USSR seismic station network make it possible to determine the absolute value of the energy of elastic oscillations radiated by a source, on the basis of the method suggested by B. B. Galitzin in $1915\left(^{(1)}\right.$ and developed by $\mathrm{H}$. Jeffreys $\left({ }^{2}\right)$. To solve this problem, it is necessary to determine the changes in the density of elastic wave energy with distance, and to work out methods for determining the energy of nonstationary oscillations.

The present communication represents the contents of two articles $\left({ }^{3,4}\right)$, connected with the question of determination the absolute value of the energy of longitudinal and transverse waves.

The value of the energy radiated by the source is that of the energy of body waves in the period range of 2 to 10 sec. where standard equipment of D. P. Kirnos type has constant magnification.

In estimating elastic energy radiated by a source we shall proceed from the following assumptions:

1. The flux of the energy transmitted from the source to the earth surface is directed along the rays.

2. The variations in the energy flux due to reflection and refraction at the intermediate underground boundaries are of the same order as the errors in determining the oscillation energy, and only the effect of the bottom of the Earth's crust and the Earth surface is taken into account.

3. The duration of elastic oscillations in $P$ and $S$ phases radiated by the source does not change in propagating towards the Earth surface.

(*) Paper read at the Helsinky Assembly of the I.U.G.G., 1960. 
In this paper the term " earthquake energy" will signify the energy of elastic body waves radiated by the earthquake source. This energy we represent as the sum of energies of longitudinal $\left(E_{p}\right)$ and transverse $\left(E_{s}\right)$ waves radiated from the source.

$$
E=E_{p}+E_{s}
$$

The calculation of the energy of $P$ or $S$ waves from the data of individual stations has been carried out by means of the following formulas:

$$
\begin{aligned}
& E^{\prime}=\frac{4 \pi R^{2} \sin \theta \sin e_{a}}{f(e, \alpha) \cos e \frac{d e}{d \theta}} e^{\chi \theta}\left(\frac{E_{o}}{\varrho c}\right) . o c \\
& E_{o}=\varrho c \int_{0}^{\tau}\left[\frac{\left.\left(\frac{d A_{N}}{d t}\right)^{2}+1 \frac{\left(d A_{E}\right.}{d t}\right)^{2}}{K_{v}^{2}}+\frac{\left(\frac{d A_{Z}}{d t}\right)^{2}}{K_{Z}{ }^{2}}\right] d t,
\end{aligned}
$$

where $\theta$ = epicentral distance, $e=$ angle of emergence of the seismic ray from the earthquake source, $k$ - coefficient of energy absorption in the Earth, $c=$ velocity of the incident $P$ or $S$ wave near the Earth surface, $\varrho=$ rock density in the vicinity of the seismic stations, $E_{o}=$ density of oscillation energy in the incident wave at the point of observation, $e_{0}=$ angle of emergence of the seismic ray to the earth surface, $A_{N}, A_{E}, A_{Z}=$ components of true ground displacement, at the earth surface $K_{N}, K_{z}=$ coefficients of reflection at the free interface for the horizontal and the vertical component respectively, $f(e, \alpha)$ function taking into account the mechanism of the earthquake source.

Energy determinations were carried out for 11 earthquakes recorded by seismic stations of the USSR. The co-ordinates of their epicentres were determined on the basis of the time of arrival of $S$ and $P$ waves at Soviet and foreign seismic stations. The basic data on the sources are given in Table 1. The geographical distribution of the epicentres is presented in Fig. 1.

142 seismograms with the most distinct recordings were selected, which served as basic material for the determination of $P$ and $S$ wave energy. These seismograms represented the records obtained by Soviet instruments " CTK" and "CBK" (records made by B. B. Galitzintype instrument were used only in two cases).

In calculating the oscillation energy we first selected the oscillation. groups corresponding to $P$ and $S$ waves in the seismograms. We cal- 
culated the energy at the point of observation for the time interval corresponding to these selected groups. The arrival of the respective wave was assumed to be the beginning of the group, its duration being determined by the time interval from the arrival to the appearance of new visible arrivals. In our cases this average duration was equal to

\section{Table 1}

\begin{tabular}{|c|c|c|c|c|c|c|c|c|c|c|}
\hline \multirow[t]{2}{*}{$\mathrm{NN}$} & \multirow[t]{2}{*}{ Data } & \multicolumn{3}{|c|}{$\begin{array}{c}\text { Time of } \\
\text { origin }\end{array}$} & \multicolumn{3}{|c|}{$\begin{array}{l}\text { Koordinates } \\
\text { of epicenter }\end{array}$} & \multirow[b]{2}{*}{$M$} & \multicolumn{2}{|c|}{$\begin{array}{l}\text { Number } \\
\text { station of } \\
\text { determining }\end{array}$} \\
\hline & & $h$ & $m$ & & $\varphi^{0}$ & $\lambda^{\circ}$ & $h_{k m}$ & & $M$ & $\lg E$ \\
\hline 1 & $26-X-1952$ & 19 & 19 & 18 & 39.4 & 143.3 & 30 & 6.2 & 15 & 13 \\
\hline 2 & $27-X-1952$ & 03 & 17 & 15 & 39.6 & 143.3 & 30 & 6.2 & 28 & 12 \\
\hline 3 & 28 -III - 1954 & 20 & 36 & 24 & 50.9 & 175.9 & 50 & 6.4 & 22 & 11 \\
\hline 4 & $1 \cdot I V-1954$ & 18 & 18 & 47 & 46.8 & 153.5 & 60 & 6.0 & 24 & 9 \\
\hline 5 & 18.VII-1954 & 09 & 07 & 41 & 36.0 & 141.0 & 40 & 6.2 & 15 & 10 \\
\hline 6 & 9.VIII-1954 & 19 & 16 & 51 & 53.3 & 160.7 & 60 & 6.2 & 26 & 8 \\
\hline 7 & 30-VIII-1954 & 07 & 57 & 24 & 43.9 & 147.4 & 60 & 5.9 & 18 & 9 \\
\hline 8 & 6-IX-1954 & 18 & 30 & 52 & 51.7 & 157.9 & 60 & 6.2 & 30 & 10 \\
\hline 9 & 23-IX-1954 & 21 & 43 & 37 & 48.6 & 156.8 & 60 & 6.3 & 21 & 13 \\
\hline 10 & 18-VIII-1957 & 21 & 42 & 36 & 50.0 & 156.5 & 40 & 6.4 & 15 & 13 \\
\hline 11 & $3-I-1957$ & 12 & 48 & 29 & 44.0 & 130.0 & 560 & 6.4 & 17 & 34 \\
\hline
\end{tabular}

the doubled time of amplitude increment after arrival. It proved to be equal on the average to about $20 \mathrm{sec}$ for $P$ and $40 \mathrm{sec}$ for $S$ waves. The abovementioned intervals were selected after a detailed consideration of many records.

In calculating the energy of the selected $P$ and $S$ groups, we assume that we determine the energy of $P$ and $S$ waves within the given frequency range. Since waves of different frequencies have different attenuation with distance, it was necessary to estimate the frequency spectrum of $P$ and $S$ waves as a function of the distance. The average periods in the $P$ and $S$ phases were measured.

The dependence of the average period on the distance in the selected groups is shown in Fig. 2. As may be seen, the average periods in the groups investigated are very similar and do not change with a 
variation in the epicentral distance (on the average, $T_{p}$ is 4-5 sec and $T_{s}-6-8$ sec.).

One may assume that starting with $\theta=20^{\circ}$ and up $P$ and $S$ wares propagate without substantial distortions or shape variations. Our

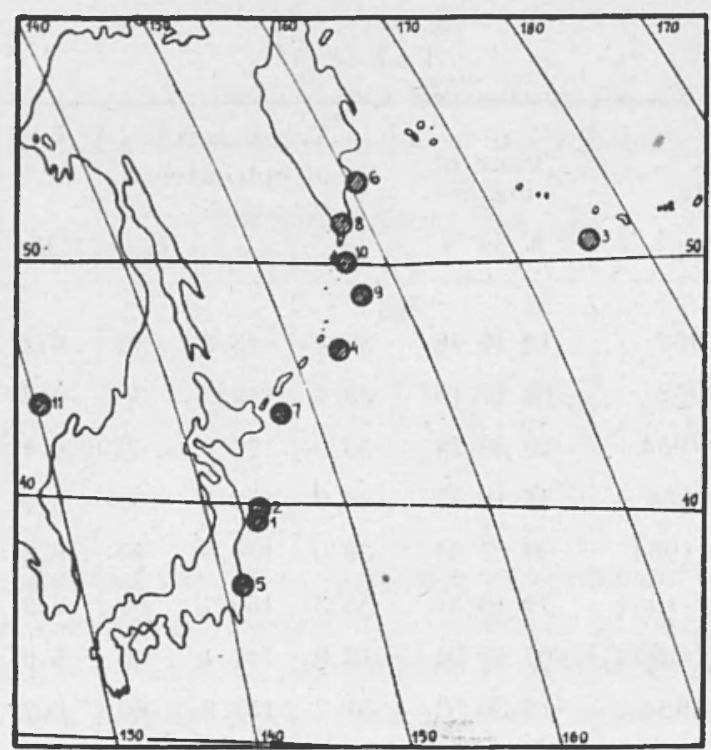

Fig. 1. - Geographical distribution of earthquake epicentres. The earthquake numbers are the same as in Table 1.

data on energy values are somewhat understated owing to the limited range of the periods under consideration.

In calculating integrals $\int_{0}^{\tau}\left(\frac{d A_{i}}{d t}\right)^{2} d t$ we departed from the usual scheme representing oscillations as sinusoid curves. The calculation of these integrals was carried out by means of a special device.

The operating principle of this device consists in the following. The seismogram is placed on the drum of a station recorder which rotates at a constant speed. A rheostat having an indicator on its slide is fixed parallel to the drum generatrix. A permanent voltage is applied at the ends of the rheostat, which is proportional to the amplitude on the seismogram at each moment of time. Further, the electronic device differentiates the oscillation curve, squares and then integrates it $\left(^{5}\right)$. The integrals were measured repeatedly, the results being continuously 
compared with the calibration sinusoid curves for which the integral value was determined numerically. The average error of individual measurements turned out to be about $20 \%$.

For calculation the amplitudes of true displacement on the earth surface, the normal magnification of the instruments was used as a divider; it is characterized by the magnification of stationary sinusoidal oscillations.

The paper by D. P. Kirnos and N. V. Kondorskaya $\left(^{8}\right)$ shows that in the case of non-stationary oscillations the instrument amplification may differ considerably from normal. An estimate was made of the cal-

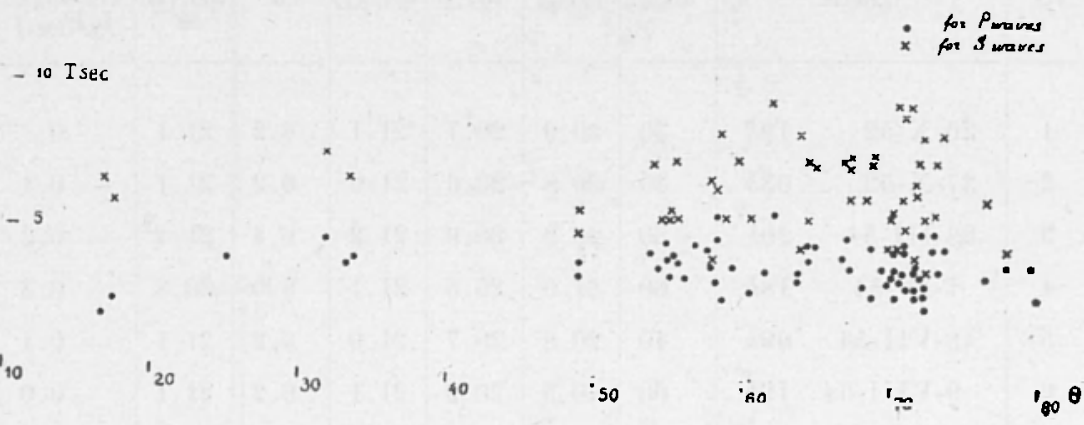

Fig. 2. - Dependence of the average period in the $P$ and $S$ phases on the epicentral distance $(\theta)$.

$$
\begin{gathered}
\ldots \text { - for } P \text { waves } \\
\mathrm{xxx} \text {-for } S \text { waves }
\end{gathered}
$$

culation error due to the adoption of stationary normal magnification. It proved to be up to $20 \%$.

The reflection coefficients at the free interface and the refraction coefficients at the intermediate boundaries have been taken from papers by B. Gutenberg ( ${ }^{7}$ ) and S. D. Kogan $\left({ }^{8}\right)$.

The function $\frac{\sin \theta \cdot \sin e_{o}}{\cos e \cdot d e}$ was calculated on the basis of Hodgson's $d \theta$

tables $\left(^{9}\right)$ and the numerical differentiation with respect to the tabulated values of $e$. Values of this function for different depths from 0 to $600 \mathrm{~km}$ were plotted.

We defined $f(e, \alpha)$ as the amount of energy per unit solid angle in the direction $e, \alpha$ as related to the average energy of the source in a unit solid angle. To calculate this, it is necessary to known the direction of the forces in the source, and the position of the seismic stations which 
is determined by the angles $e$ and $\alpha$. For the calculations of $f(e, \alpha)$ we employed the equations for displacements in $P$ and $S$ waves suggested by Keilis-Borok $\left({ }^{10}\right)$. The source mechanism was studied specially for one of the earthquakes of the series under review, namely that of January 3,1957 , on the basis of distribution of displacement signs upon the arrival of $P . S V, S H$ and $P_{c} P$ waves at the seismic stations. The force system of this earthquake is modelled by a double force with a

Table 2

\begin{tabular}{|c|c|c|c|c|c|c|c|c|c|}
\hline NN & Data & & $h_{k m}$ & $\lg E_{p}$ & $\lg E_{s}$ & $\lg E_{p+s}$ & $M$ & $\lg E_{(u)}$ & $\begin{array}{c}\Delta \lg E \\
\left(\lg E_{p+s^{-}}\right. \\
\left.\lg E_{(M)}\right)\end{array}$ \\
\hline I & $26-\mathrm{X}-52$ & $19 h$ & 30 & 20.9 & 20.7 & 21.1 & 6.2 & 21.1 & 0 \\
\hline 2 & $27-X-52$ & $03 \hbar$ & 30 & 20.8 & 20.6 & 21.0 & 6.2 & 21.1 & -0.1 \\
\hline 3 & 28-III-54 & $20 h$ & 50 & 20.9 & 20.9 & 21.2 & 6.4 & 21.4 & -0.2 \\
\hline 4 & $1-I V-54$ & $18 h$ & 60 & 21.0 & 20.5 & 21.1 & 6.0 & 20.8 & +0.3 \\
\hline 5 & 18-VII-54 & 097 & 40 & 20.8 & 20.7 & 21.0 & 6.2 & 21.1 & -0.1 \\
\hline 6 & 9 -VIII-54 & $19 h$ & 60 & 20.5 & 20.9 & 21.1 & 6.2 & 21.1 & 0.0 \\
\hline 7 & 30-VIII-54 & $07 h$ & 60 & 20.7 & 20.7 & 21.0 & 5.9 & 20.7 & +0.3 \\
\hline 8 & 6-IX-54 & $18 h$ & 60 & 20.7 & 20.9 & 21.1 & 6.2 & 21.1 & 0.0 \\
\hline 9 & $23-\mathrm{IX}-54$ & $21 h$ & 60 & 20.6 & 20.8 & 21.0 & 6.3 & 21.3 & -0.3 \\
\hline 10 & 18-VIII-57 & $21 h$ & 40 & 20.3 & 20.3 & 20.6 & 6.4 & 21.4 & -0.8 \\
\hline I I & $3-\mathrm{I}-57$ & $12 h$ & 560 & 20.45 & 20.65 & 20.9 & 6.4 & 21.4 & -0.5 \\
\hline
\end{tabular}

moment, the forces forming a plane extending at $303^{\circ}$ and inclined at $10^{\circ}$. The movement in the rupture plane is nearly horizontal. The determination of the direction of forces in the source of this earthquake was helpful in determining $f(e, a)$ which varied between 0 and 1 for the system of the stations used. It turned out that the scatter of $E$ values for individual stations exceeded $f(e, \alpha)$ variations.

For the other 10 earthquakes we assumed $f(e, \alpha)=1$.

In calculating the average $E$ value for each earthquake, we determined the average geometrical of all values calculated for individual seismic stations.

$$
E=1 \overline{E_{1}: E_{2} \ldots E_{n}},
$$

where $n=$ number of stations whose data served to determine the energy. 
In this case $E=\sqrt{\bar{E}_{1} \cdot \bar{E}_{2} \cdot E_{3} \ldots E_{n} \cdot e^{k\left(\theta_{1}+\theta_{2}+\theta_{3}+\ldots \theta_{n}\right)}}$ where $E=E e^{-k \theta}, k=0.00012^{k} m^{-1} \quad$ (Gutenberg's value).

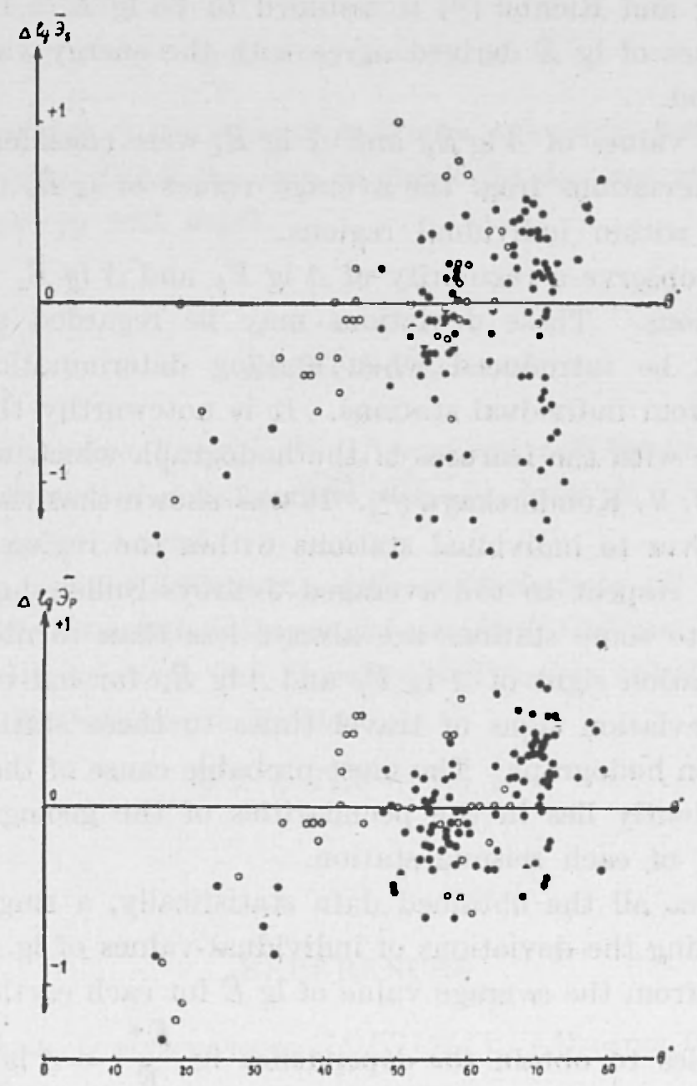

Fig. 3. - Experimental data on $\Delta \lg E_{p}$ and $A \lg E_{s}$ $A \lg E_{p}=\lg E_{p} *$ (individual) - $\lg E_{p}$ (average) $A \lg E_{s}=\lg E_{s}^{*}$ (individual) - $\lg E_{s}$ (average) as a function of the epicentral distance $(\theta)$. $\ldots$ - experimental data on earthquakes No. 1-10 ooo - experimental data on earthquake No. 11

Taking into account all the values indicated, we obtained the values of the energy of $P$ and $S$ waves reduced to the source. They are presented in Table 2 .

The data of the Table enable the following conclusions to be drawn:

1. The average values of $\lg E_{p}$ and $\lg E_{s}$ are very similar. 
2. All the earthquakes under consideration have nearly identical values of $M$. The energy values obtained are also rather close.

3 . If the relationship of the $M$ value and the energy as obtained by Gutenberg and Richter (11) is assumed to be $\lg E=11.8+1.5 \mathrm{M}$, then the values of $\lg E$ derived agree with the energy values obtained by our method.

4. The values of $\Delta \lg E_{p}$ and $\Delta \lg E_{s}$ were considered, which represent the deviations from the average values of $\lg E_{p}$ and $\lg E_{s}$ for each station within individual regions.

One can observe a regularity of $\Delta \lg E_{p}$ and $\Delta l g E_{s}$ values for individual stations. These deviations may be regarded as corrections which should be introduced when making determinations according to the data from individual stations. It is noteworthy that these corrections agree with the features of the hodograph which were previously noted by $\mathrm{N}$. V. Kondorskaya $\left({ }^{12}\right)$. It was shown that the travel times of seismic waves to individual stations within the region exhibit a regularity with respect to the averaged Jeffreys-Bullen hodograph: the travel times to some stations are always less than to others.

The deviation signs of $\Delta \lg E_{p}$ and $\Delta \lg E_{s}$ for individual stations agree with deviation signs of travel times to these stations from the Jeffreys-Bullen hodograph. The most probable cause of these deviations obtained evidently lles in the peculiarities of the geological structure in the region of each seismic station.

To analyse all the obtained data statistically, a single graph was used for plotting the deviations of individual values of $\lg \bar{E}^{*}$ for individual stations from the average value of $\lg E$ for each earthquake. Such plotting enables to obtain the dependence $\lg \frac{E^{*}}{E}=\Delta \lg E=f(\theta)$ for earthquakes of different intensities. The respective dependences $\Delta \lg E=f(\theta)$ for $P$ and $S$ waves are given in Fig. 3 .

In spite of the considerable scatter of individual values, the general trend is toward an increase in $\Delta \lg E$ with the epicentral distance which may be due to the decrease in the absorption coefficient of energy with depth.

\section{$S U M M A R Y$}

The energy of 11 earthquakes in the Far East was examined by using observations of seismic stations of the USSR with epicentral distances from $20^{\circ}$ up. 
The absolute value of energy of elastic waves $(P$ and $S)$ was determined on the basis of development of Galitzin method.

The results agree with the value of energy calculated on the basis of Gutenberg and Richter formula.

$$
\lg E=11.8+1.5 \mathrm{M} .
$$

The dependence of the value of $\lg E$ with epicentral distance was noticed. It is suggested that this way be due to the decrease with absorption coefficient of energy with depth.

\section{RIASSUNTO}

E stata esaminata l'energia di 11 terremoti nell'Estremo Oriente utilizzando le osservazioni delle stazioni sismiche dell'U.R.S.S. con distanze dall'epicentro da $20^{\circ}$ in poi.

Il valore assoluto dell'energia delle onde elastiche $(P$ ed $E)$ e stato determinato sulla base dello sviluppo del metodo di Galitzin.

I risultati concordano con il valore dell'energia calcolato sulla base della formula di Gutenberg e Richter

$$
\lg E=11,8+1,5 M
$$

\section{REFERENCES}

(1) Б. В. Голицин, О землетрясении 18/II/1911 г., " Изветня Росс. АН," cер. 6,1915 r.

(2) Jefrems H., The Pamir earthquale of 1911 February 18 in relation to depth of earthquake foci. "Mon. Not. Roy. Astronom. Soc. Geophys.", Suppl. 1, 2, (1923).

(3) Е. Ф. САВАРенСКИи, Н. В. КоНДоРСКАЯ, В. Л. ВЕЛОТЕЛОБВ, Об определении энергии упругих волн, поролсдаемых землетрясением, Известия АН СССР, Серя геофизическая, № 5, 1960.

(4) В. Л. БЕЛОТЕЛов, Н. В. КондорСКАЯ, $K$ вопросу определения энеригии землетрясения, Нзвестия АН СССР, Серия геофиз., № 12, 1960.

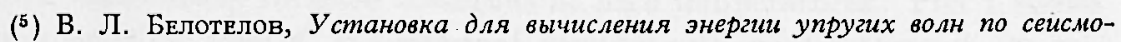
граммам, Известия АН СССР ОТН, № 6, 1959.

${ }^{6}{ }^{6}$ Д. П. Кирнос, Н. В. КондорскАя, О выкчислении истинного значения первой амплитуды дөиэсения почвы при вступлении сеисмическои волны, "Нзв. " АН СССР, Сер. геофиз. № 12, 1958. 
(7) GUTENBERG B., Energy ratio of reflected and refracted seismic waves. "Bull. of the Seismol. Soc. of America ", 34, 2, (1944).

(8) С. Д. КогАН, Параметры очагов глубокофокусных землетрлселии, “Труды геофизического ииститута », № 30 (157), 1955.

(') Hodgson H., Storey R., Tables extending Byerly's fault plane techniques to earthquakes of any focal depth. "Bull. Seism. Soc. Am. ", 43, (1953).

(10) В. И. КЕилис-Борок, Графические методы расчета динанических параметров очага землетрясения, Известия АН СССР, Сер. геофиз. № 6, 1951.

(11) Gutenberg B., Richter C. F., Magnitude and energy of earthqualies "Ann. Geofis. ", Roma, 9, 1, (1956).

(12) Н. В. Кондорская, По поводу региональных особенностеи еремен пробега сеисмических волн, Известия АН СССР, Сер. геофиз., № 7, 1957. 